\title{
Effect of Storage on Quality of Tamarind (Tamarindus indica L.) Clones
}

\author{
Ranjita Devi Takhellambam ${ }^{1 *}$ and Pushpa Bharati ${ }^{2}$ \\ ${ }^{1}$ Department of Home Science, Competitive Success Academy, \\ Manipur, Imphal-795001, India \\ ${ }^{2}$ Department of Food Science and Nutrition, College of Rural Home Science, \\ Dharwad, Karnataka, India \\ *Corresponding author
}

\section{A B S T R A C T}

\section{Keywords \\ Tamarind, Clones, moisture, Titratable acidity, Tartaric acid, Colour}

\section{Article Info}

Accepted:

20 July 2020

Available Online:

10 August 2020
Five clones of released and pre-released tamarind clones (NTI-79, NTI-19, NTI14, SMG-13 and PKM-1) were obtained from department of farm forestry, University of Agricultural Sciences, Dharwad for evaluating the storage quality. Deseeded and cleaned fruits were packed in LDPE pouches, sealed in tight and stored at ambient temperature for five months. Monthly observations were recorded. Throughout the storage period, there was increase in the moisture content from 9.45 (fresh) to 16.73 per cent at the fifth month of storage and higher increase was observed in NTI-79 (13.63\%). Titratable acidity was higher in NTI$19(11.43 \%)$ and low in PKM-1 (7.6\%). The clones SMG-13 (11.39\%) and PKM$1(11.53 \%)$ exhibited significantly lower increase in tartaric acid content while NTI-14 contained higher level (17.81\%) irrespective of storage period. Throughout the storage period colour of the pulp of different clones darkened with a varying intensity. No insect infestation was observed throughout the storage period of five months in all the clones. NTI-19 had better characters after storage.

\section{Introduction}

Tamarind (Tamarindus indica) or Imli, is a dicotyledonous plant belonging to Leguminasae family which is also called as Indian Date. Tamarind is native to tropical Africa and grows wild throughout Sudan. It was introduced to India so long ago that it is now reported as indigenous. It is abundant in the Madhya Pradesh, Bihar, Andhra Pradesh, Karnataka, Tamil Nadu and West Bengal.
Tamarind grows successfully in variety of soils ranging from red gravel loam to degraded wastelands. However, tree thrives best on well-drained deep loamy or alluvial soils. Ripe fruits are harvested during February-April by shaking the branches. Fruits are also harvested at half ripe stage. The fresh fruits are dried using small-scale dehydrators; however in rural areas pods are dried in the sun. To preserve tamarinds for future use, the shells, fibers and seeds are 
separated; pulp is compressed and packed in baskets, jute bags or plastic bags for storage and marketing. The pulp is preserved in large masses and sold in small shops and market by weight. In East India, the pulp is covered with salt, rolled into balls, exposed to dew and stored in earthenware jars (Chapman 1984 and Julia et al., 1987). The quality and condition of the pulp and the selling price in the market are often related to the care taken during storage. The freshly prepared pulp is light brown in colour, but darkens on storage. Generally, under dry conditions, the pulp remains good for about one year, after which it becomes almost black. The storage quality depends on temperature and packing materials. Hence the present study was undertaken with an objective to study the storage quality of selected tamarind clones.

\section{Materials and Methods}

Fresh fruits of NTI-79, NTI-19, NTI-14, SMG-13 and PKM-1 were obtained from the Department of Farm Forestry UAS, Dharwad in 2011. The pods were processed by separating shell, seed, pulp and fiber. After processing, $100 \mathrm{~g}$ of pulp was packed in LDPE (Low Density Polyethelyne) pouches and stored at ambient temperature for a period of five months. The samples were drawn at monthly interval to evaluate the quality in terms of moisture gain, titrable acidity, tartaric acid (Ranganna, 1986). Colour of the samples drawn monthly was compared with Horticulture Colour Chart developed by the British Colour Council, London and recorded. The samples were also observed visually for insect infestation.

\section{Results and Discussion}

Effect of storage on moisture content of tamarind pulp is given in Table 1. Throughout the storage period, there was increase in the moisture content from 9.45 (fresh) to 16.73 per cent at the fifth month of storage. The increase in moisture differed significantly in different clones. Over a period of five months, higher increase was significantly observed in NTI-79 (13.63\%) and the minimum was recorded in SMG-13 (12.03\%). Tamarind fruit being hygroscopic in nature has the tendency to absorb moisture during storage. Ramkumar et al., (1997) also reported that there was increased in moisture content when stored in transparent polyethylene covers. Further Lewis and Neelakantan (1964) and Anon. (1976) also stated that after storage of one year, the pulp also becomes soft and sticky as pectolytic degradation takes place and moisture is absorbed, especially in humid weather

Nearly 92 per cent gain in moisture over fifth month storage period was recorded in NTI-14 and SMG-13. Percent increase in moisture was found to be lower in PKM-1(58.42\%) throughout the storage period (Fig.1).

Table 2 depicts the effect of storage on titratable acidity of tamarind clones. All the clones differed significantly with regard to titratable acidity. Mean initial titratable acidity was significantly higher in NTI-19 $(11.43 \%)$ and low in PKM-1. Irrespective of clones, as the storage period increases the mean titratable acidity goes on increasing from $8.63 \%$ (when fresh) to $11.23 \%$ (after fifth month) of storage in all the clones tested. The increase in titratable acid content was reported in fig leather (Kotlawar, 2008), high protein tamarind leather (Kharche, 2012) and in guava leather packed in different packaging materials, at different storage conditions (Safdar, 2014 and Basha, 2018). The results obtained in present investigation are parallel to earlier reports. However contradictory findings was reported by (Pattar et al., 2013) which indicated that decrease titratable acidity was recorded in tamarind paste, T7 (12.48\%, $12.45 \%$ and $12.42 \%$ ) at 30, 60 and 90 days after storage, respectively. 
The percent increase in titratable acidity was steady up to fourth month and almost doubled during fifth month (Fig. 2). NTI-14 recorded the maximum $(37.06 \%)$ increase and minimum increase was found in NTI-19 $(26.34 \%)$. The increased in titratable acid might be due to the breakdown of carbohydrate and proteins into fraction of acids.

The most outstanding characteristic of tamarind is its sweet acidic taste, the acidity is due mostly to tartaric acid (2,3dihydroxybutanedioic acid, $\mathrm{C}_{4} \quad \mathrm{H}_{6} \quad \mathrm{O}_{6}$, a dihydroxydicarboxylic acid), ranging from $12.2-23.8 \%$, and uncommon in other plant tissues (Ulrich, 1970). It is an unusual plant acid, which is formed from the primary carbohydrate products of photosynthesis, and once formed, it cannot be further used in the plant due to the absence of the necessary enzymes. Although tartaric acid occurs in other sour fruits, such as grapes, grapefruit and raspberries, it is not present in such high proportions as in tamarind. However storage of tamarind pulp also had an effect on tartaric acid content. In fresh tamarind, the tartaric acid was a least of 10.56 per cent in SMG-13 and highest of 16.69 per cent in NTI-14.This correspondingly increased to 12.7 and 20.26 per cent at the end of storage period of five months (Table 3). The varieties SMG-13 (11.39\%) and PKM-1(11.53\%) exhibited significantly lower in tartaric acid content while NTI-14 contained higher level $(17.81 \%)$ irrespective of storage period.

The PKM-1 and SMG-13 possessed similar amounts of tartaric acid on storage. Per cent increase in tartaric acid was maximum in NTI-79 and minimum in SMG-13, low tartaric acid variety (Fig. 3). The increased in tartaric acid also might be due to the breakdown of carbohydrate and proteins into fraction of acids.

Table.1 Effect of storage on moisture (\%) content of tamarind clones

\begin{tabular}{|c|c|c|c|c|c|c|}
\hline \multirow[t]{2}{*}{ Clones } & \multicolumn{5}{|c|}{ Storage period in months } & \multirow[t]{2}{*}{ Mean } \\
\hline & $\mathbf{0}$ & 1 & 2 & 4 & 5 & \\
\hline NTI-14 & 8.61 & 10.97 & 11.91 & 14.82 & 16.58 & 12.57 \\
\hline NTI-19 & 9.80 & 11.55 & 12.44 & 15.3 & 17.09 & 13.23 \\
\hline NTI-79 & 10.15 & 11.75 & 12.56 & 16.15 & 17.56 & 13.63 \\
\hline PKM-1 & 10.51 & 11.85 & 11.97 & 15.1 & 16.65 & 13.21 \\
\hline SMG-13 & 8.21 & 10.5 & 11.37 & 14.29 & 15.79 & 12.03 \\
\hline \multirow[t]{2}{*}{ Mean } & 9.45 & 11.32 & 12.05 & 15.13 & 16.73 & \\
\hline & 'F' value & \multicolumn{2}{|c|}{$\mathrm{SEm} \pm$} & \multicolumn{3}{|c|}{ C.D. } \\
\hline $\begin{array}{l}\text { Variety } \\
\text { (V) }\end{array}$ & 1.37 & \multicolumn{2}{|c|}{0.091} & \multicolumn{3}{|c|}{$0.346 * *$} \\
\hline $\begin{array}{l}\text { Storage } \\
\text { Period (M) }\end{array}$ & 2.68 & \multicolumn{2}{|c|}{0.091} & \multicolumn{3}{|c|}{$0.346 * *$} \\
\hline $\begin{array}{l}\text { Interaction } \\
(\mathbf{V} \times \mathbf{M})\end{array}$ & 62.332 & \multicolumn{2}{|c|}{0.041} & \multicolumn{3}{|c|}{$0.155 * *$} \\
\hline
\end{tabular}

Note: Values are mean of 3 replications

**significant at $1 \%$

No data available for $3^{\text {rd }}$ month 
Table.2 Effect of storage on titratable acidity (\%) of tamarind clones

\begin{tabular}{|c|c|c|c|c|c|c|}
\hline \multirow[t]{2}{*}{ Clones } & \multicolumn{5}{|c|}{ Storage period in months } & \multirow[t]{2}{*}{ Mean } \\
\hline & $\mathbf{0}$ & 1 & 2 & 4 & 5 & \\
\hline NTI-14 & 8.93 & 9.23 & 9.31 & 9.72 & 12.24 & 9.88 \\
\hline NTI-19 & 10.25 & 11.05 & 11.37 & 11.55 & 12.95 & 11.43 \\
\hline NTI-79 & 9.37 & 10.12 & 10.44 & 11.53 & 12.09 & 10.71 \\
\hline PKM-1 & 6.9 & 7.01 & 7.29 & 7.64 & 9.16 & 7.6 \\
\hline SMG-13 & 7.7 & 7.83 & 8.15 & 9.04 & 9.75 & 8.49 \\
\hline \multirow[t]{2}{*}{ Mean } & 8.63 & 9.04 & 9.31 & 9.89 & 11.23 & \\
\hline & 'F' value & SEm \pm & \multicolumn{3}{|c|}{ C.D. } & \\
\hline Variety (V) & 5.66 & 0.100 & \multicolumn{3}{|c|}{$0.379 * *$} & \\
\hline $\begin{array}{l}\text { Storage Period } \\
\text { (M) }\end{array}$ & 2.33 & 0.100 & \multicolumn{3}{|c|}{$0.379 * *$} & \\
\hline $\begin{array}{l}\text { Interaction ( } \mathbf{V} \mathbf{x} \\
\text { M) }\end{array}$ & 55.26 & 0.045 & \multicolumn{3}{|c|}{$0.169 * *$} & \\
\hline
\end{tabular}

Note: Values are mean of 3 replications

$* *$ significant at $1 \%$

No data available for $3^{\text {rd }}$ month

Table.3 Effect of storage on tartaric acid (\%) of tamarind clones

\begin{tabular}{|l|c|c|c|c|c|c|}
\hline \multirow{2}{*}{ Clones } & \multicolumn{7}{|c|}{ Storage period in months } & \multirow{2}{*}{ Mean } \\
\cline { 2 - 7 } & $\mathbf{0}$ & $\mathbf{1}$ & $\mathbf{2}$ & $\mathbf{4}$ & $\mathbf{5}$ & \\
\hline NTI-14 & 16.69 & 17.09 & 17.29 & 17.72 & 20.26 & 17.81 \\
\hline NTI-19 & 15.18 & 16.18 & 16.52 & 16.72 & 18.32 & 16.58 \\
\hline NTI-79 & 13.01 & 14.27 & 14.62 & 15.74 & 16.32 & 14.79 \\
\hline PKM-1 & 10.79 & 10.92 & 11.22 & 11.6 & 13.14 & 11.53 \\
\hline SMG-13 & 10.56 & 10.71 & 11.05 & 11.96 & 12.7 & 11.39 \\
\hline Mean & 13.24 & 13.83 & 14.14 & 14.74 & 16.14 & \\
\hline & 'F' value & SEm \pm & & C.D. & \\
\hline Variety (V) & 576.615 & 0.604 & & $2.288^{* *}$ & \\
\hline $\begin{array}{l}\text { Storage Period } \\
\text { (M) }\end{array}$ & 70.434 & 0.604 & & $2.288^{* *}$ & \\
\hline $\begin{array}{l}\text { Interaction } \\
\text { (V x M) }\end{array}$ & 3.455 & & & & & \\
\hline
\end{tabular}

Note: All values are mean of 3 replications

** Significant at $1 \%$

No data available for $3^{\text {rd }}$ month 
Table.4 Effect of storage on colour of tamarind clones

\begin{tabular}{|c|c|c|c|c|c|}
\hline \multirow[t]{2}{*}{ Clones } & \multicolumn{5}{|c|}{ Storage period in months } \\
\hline & 0 & 1 & 2 & 4 & 5 \\
\hline NTI-14 & $\begin{array}{l}\text { Orpiment } \\
\text { orange } 10 \\
\text { (Buff) }\end{array}$ & $\begin{array}{l}\text { Purple } \\
\text { madder } \\
1028 \\
\text { (Brown) }\end{array}$ & $\begin{array}{l}\text { Garnet brown } \\
00918 \text { (Brown) }\end{array}$ & $\begin{array}{l}\text { Purple } \\
\text { madder } \\
1028 / 2 \\
\text { (Brown) }\end{array}$ & $\begin{array}{l}\text { Chrysanthmum } \\
\text { crimson } 824 \\
\text { (Black) }\end{array}$ \\
\hline NTI-19 & $\begin{array}{l}\text { Nasturtium } \\
\text { orange } 610 \\
\text { (Light } \\
\text { Brown) }\end{array}$ & $\begin{array}{l}\text { Purple } \\
\text { madder } \\
1028 \\
\text { (Brown) }\end{array}$ & $\begin{array}{l}\text { Oxblood red } \\
00823 \text { (Brown) }\end{array}$ & $\begin{array}{l}\text { Purple } \\
\text { madder } \\
1028 / 3 \\
\text { (Brown) }\end{array}$ & $\begin{array}{l}\text { Pansy purple } 928 \\
\text { (Black) }\end{array}$ \\
\hline NTI-79 & $\begin{array}{l}\text { Persimon } \\
\text { orange } 710 \\
\text { (Reddish) }\end{array}$ & $\begin{array}{l}\text { Purple } \\
\text { madder } \\
1028 / 1 \\
\text { (Brown) }\end{array}$ & $\begin{array}{l}\text { Garnet brown } \\
\text { 00918/1(Brown) }\end{array}$ & $\begin{array}{l}\text { Purple } \\
\text { madder } \\
1028 \\
\text { (Brown) }\end{array}$ & $\begin{array}{l}\text { Oxblood red } \\
00823 \text { (Slight } \\
\text { black) }\end{array}$ \\
\hline PKM-1 & $\begin{array}{l}\text { Yellow } \\
\text { ochre } 07 \\
\text { (Light buff) }\end{array}$ & $\begin{array}{l}\text { Garnet lake } \\
828 \\
\text { (Brown) }\end{array}$ & $\begin{array}{l}\text { Oxblood red } \\
\text { 00823/3 (Brown) }\end{array}$ & $\begin{array}{l}\text { Garnet } \\
\text { brown } \\
00918 \\
\text { (Brown) }\end{array}$ & $\begin{array}{l}\text { Oxblood Red } \\
\text { 00823/1 (Slight } \\
\text { black) }\end{array}$ \\
\hline SMG-13 & $\begin{array}{l}\text { Marigold } \\
\text { orange } 11 \\
\text { (Pale } \\
\text { brown) }\end{array}$ & $\begin{array}{l}\text { Oxblood } \\
\text { red 00823/2 } \\
\text { (Brown) }\end{array}$ & $\begin{array}{l}\text { Garnet brown } \\
\text { 00918/3 (Brown) }\end{array}$ & $\begin{array}{l}\text { Oxblood red } \\
00823 \\
\text { (Brown) }\end{array}$ & $\begin{array}{l}\text { Garnet brown } \\
00918 \text { (Black) }\end{array}$ \\
\hline
\end{tabular}

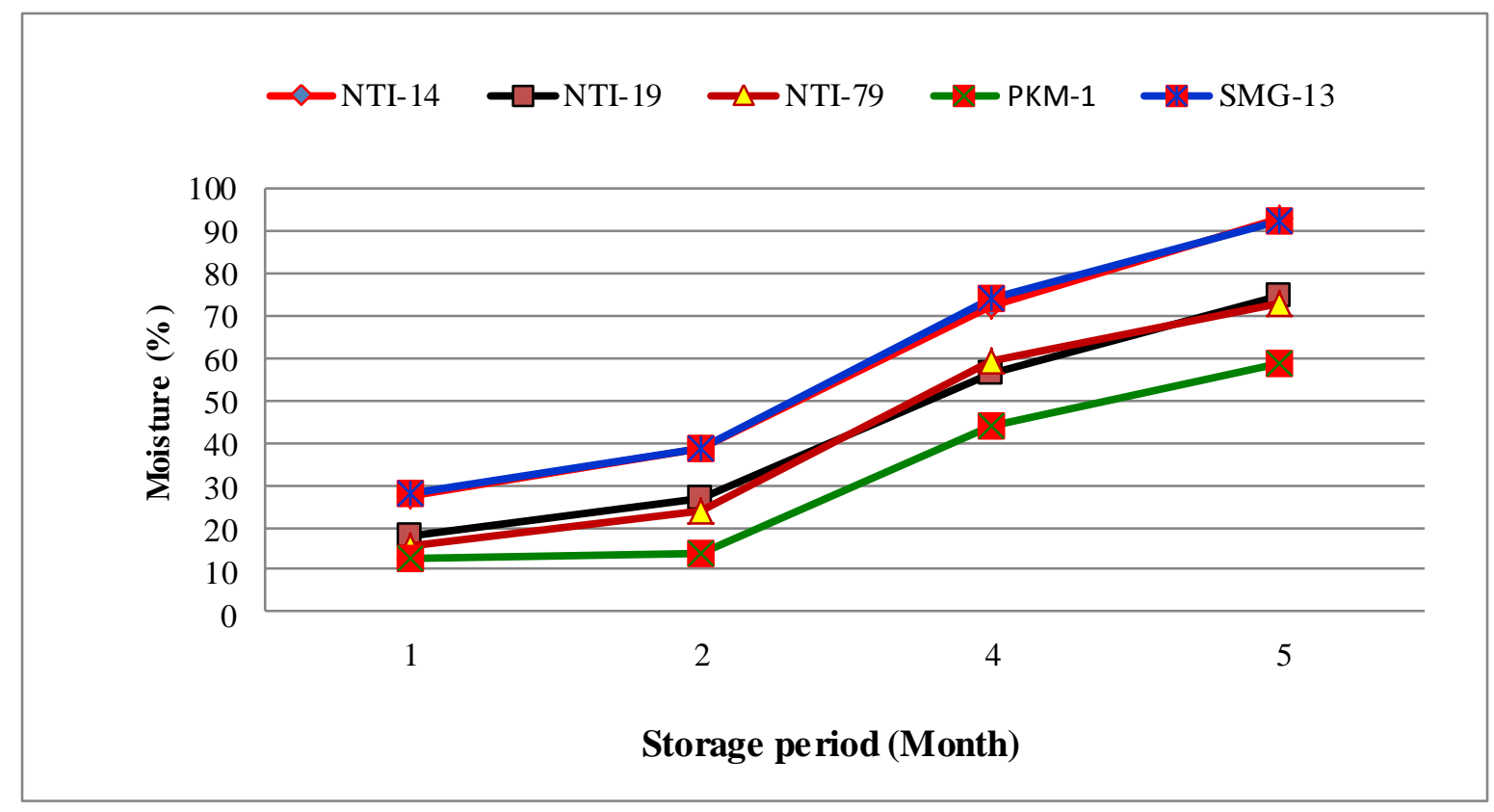

Fig.1 Percentage increase in moisture on storage of fruit 


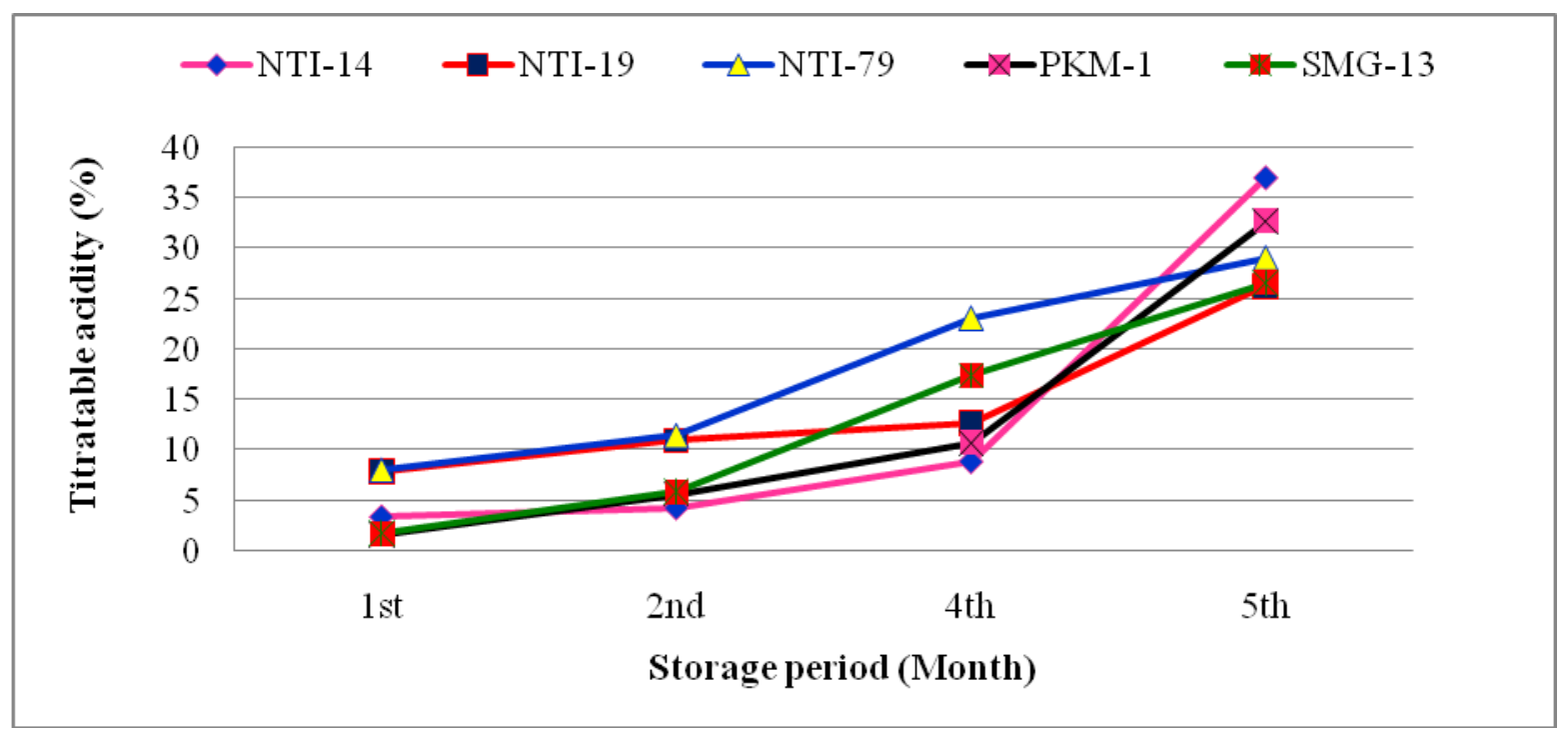

Fig.2 Percentage increase in titratable acidity of stored fruit

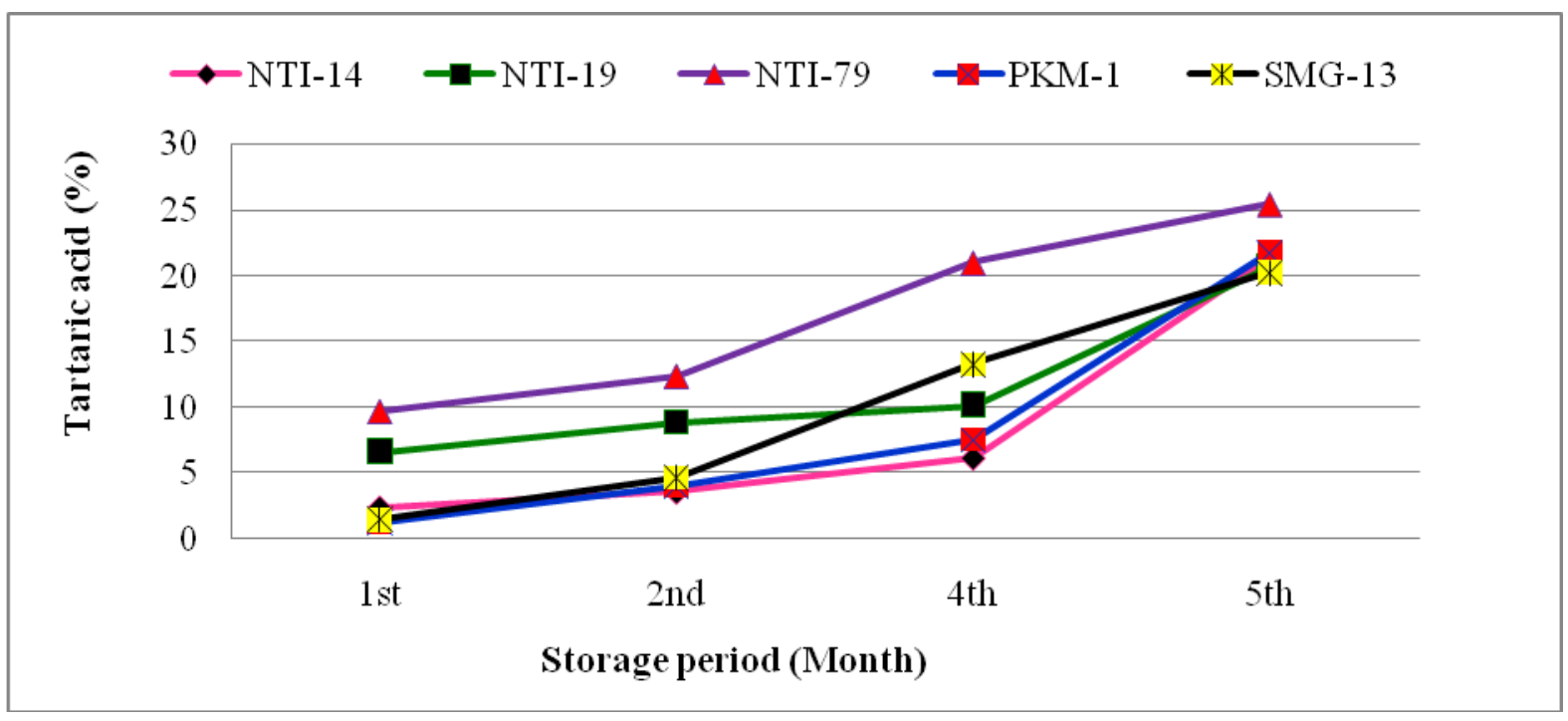

Fig.3 Percentage increase in tartaric acid of stored fruit

Effect of storage on the colour of tamarind pulp is presented in Table 4. Throughout the storage period, colour of the pulp of different clones darkened with varying intensity. Similar findings was reported by Sinha et al., (2015) which reported that tamarind pulp became darker, greener and bluer on $60^{\text {th }}$ days of storage at room temperature than its initial stage. In the present findings, the colour of NTI-14 changed from orpiment orange 10 to chrysanthemum crimson 824 after fifth months of storage. Initially the clone NTI-19 was Nasturtium orange which has been changed to Pansy purple 928. The fresh fruits of clones NTI-79 and PKM-1 were Persimon orange 710 and yellow ochre 07 changed to oxblood red 00823 and oxblood red 00823/3. SMG-13 showed marigold orange 11 when fresh and turned to garnet brown 00918. On storage in polyethylene pouches after heat sealing and storing at ambient temperature, there was darkening of colour which can be 
reasoned to the activity of polyphenol oxidase, catalase and peroxidase. Kotecha and Kadam (2003), Obulesu and Bhattacharya (2010) also reported that the increased activity of enzymes with the advancement of storage period leading to enzymatic browning thus darkening the colour of the pulp. In addition the presence of sugars especially reducing sugar and lysine might have initiated maillard reaction resulting in browning (Ajandouz and Puigserver, 1999). Further FAO (1989) also stated that continuous storage for long periods under poor conditions, such as exposure to extremes of temperature and humidity leads to change in colour which take place from brown or yellowish brown to black.

No insect infestation was observed throughout the storage period of five months in all the clones.

\section{References}

Ajandouz, E.H., and Puigserver, 1999.A non enzymatic browning reaction of essential amino acids; Effect of $\mathrm{pH}$ on caramalization and Maillard reaction kinetics. J. Agric. Food Chemistry, 47: 1786-1793.

Anonymous, 1976. Tamarindusindica L. In The Wealth of India (Raw Materials Series). Council of Scientific and Industrial Research, New Delhi, Vol.X: 144-122.

Basha, S. J. 2018. Effect of Storage Period on Physio-Chemical Properties of Guava Fruit Leather. Int.J.Curr. Microbiol.App.Sci., 7(4): 1738-1751.

Chapman, K.R. 1984.Tamarind in tropical tree fruits for Australia. Queensland Department of Primary Industries, Information Series, Brisbane, pp. 83-86.

FAO, 1989. Prevention of Post-harvest Losses: Fruits, vegetables and root crops. FAO Training Series No. 17/2.
Rome.

Horticulture colour chart, The Britishcolour council in collaboration with The Royal Horticultural Society, AC No. 5780, 6942, 6943.

Julia, F., Morton and Miami, F.L. 1987. In fruits of warm climate. Morton Journal, 115-121.

Kharche, K.M. 2012.Studies on preparation of high protein leather from tamarind. M.Sc. Thesis, M.P.K.V., Rahuri.

Kotlawar, N.G. 2008. Investigations on preparation and shelf life of fig leather. M.Sc. Thesis, M.P.K.V., Rahuri.

Kotecha, P.M. and Kadam S.S. 2003.Studies on browning in tamarind pulp during storage. J. Food Sc. Tech., 40(4): 398399.

Lewis, Y.S. and Neelakantan, S. 1964. The chemistry, biochemistry and technology of tamarind. J. Sci. Industrial Res., 23: 204.

Obulesu, M. and Bhattacharya, S. 2010.Colour changes of tamarind (Tamarindus indica L.) pulp during fruit development, ripening and storage. Int. J. Food Properties, 14(3): 538-549.

Pattar, A., Kukanoor, L., Hegde, N.K. and Jholgiker, P. 2013. Studies on keeping quality of tamarind paste during storage. TheAsian J. Hort., 18 (2): 430-432.

Ramakumar, M. V., Babu, C. K., Subramanya, S., Ranganna, B. and Krishnamurthy, K. C. 1997. Development of a Tamarind Dehuller and Short-term Storage of Pulp, Proceedings of National Symposium on Tamarindus indica L., Tirupathi, Andhra Pradesh, 27-28 June, 1997, pp. 145-50.

Ranganna, S. 1986.Handbook of analysis and quality control for fruit and vegetable products. Tata McGrawl-Hill Publishing Co. Ltd. New Delhi, pp. 3-10.

Safdar, M. N. 2014. Quality of guava leather as influenced by storage period and 
packaging material. Sarhad J. Agric., 30(2): 247-256.

Sinha, G., Patel, S., Agrawal, A.K., Mishra, N. K. and Sinha A. K. 2015. Some Studies on Assessment of Physical Properties of Tamarind Pulp. Int. J. Res.
Studies Biosc., ISSN 2349-0357 (Print) and ISSN 2349-0365 (Online) 43-47.

Ulrich, R. 1970. Organic acids. In The Biochemistry of Fruits and Their Products Vol. 1, Hulme, A.C., (Ed.), Academic Press, New York.

\section{How to cite this article:}

Ranjita Devi Takhellambam and Pushpa Bharati. 2020. Effect of Storage on Quality of Tamarind (Tamarindus indica L.) Clones. Int.J.Curr.Microbiol.App.Sci. 9(08): 2409-2416. doi: https://doi.org/10.20546/ijcmas.2020.908.275 